Left, contained one large calculus of the same kind, occupying whole pelvis.

Bladder normal. Mesenteric glands enlarged. Calf of right leg contained a large mass of blond and some pus. The opening in the artery could not be found, but the blood probibly came from the small arteries about the knee-joint.

Miicroscopic Wxamination.-Blood was about two thirds white corpuscles, large, with only one nucleus, in some instances almost as large as the cell.

Spleen contained similar elements, with the usual fusiform cells.

Lymphatic gitands contained uninuclear cells much smaller than those in the blood, the cell being inuch less distinct than the nucleus. The liver had many cells of various sizes, perhaps on the whole the cclls being small and crowded. Otherwise healthy.

'The softened portions of brain contained many round compound fatty bodies (inflammation or granulation corpuscle) and some cells retaining more or less of their processes and original shape, but much degenerated ; the latter cells especially in cerebellum.

These two cases are not offered as exceptional, but as contributions to the natural history of a somewhat rare disease. Though diflering in some important particulars, they agreed with each other or with cases elsewhere described in many points. Such are:

The occurrence of the large white corpuscle usually found in the splenic as distinguished firom the lymphatic variety ;

The presence of rhomboidal crystals, described by Dr. Ellis in a similar case, and called by him lencosin;

The hemorrhages, common ;

The appetite, to say the least, very good. This is a somewhat remarkable symptom, when we remember that increased appetite follows the removal of the spleen in dogs.

'The failure of the special senses.*

* Since the above report wiss read. I have olstivined atditional information on the suliject of the erystals found in the blood in the first ense.

As thove meutioned, Dr. dillis has reported a ense of splenic: lencocythimmin (Extratets from the Hecords of the Boston society for Medical Improverment, vol. iv., 18(i1, 1. 251), in which he found the same crystals.

In the Archir far Mikroskopischo Anatomie, Bad, ii., s. 508 , prof'. Neunum reports in casc of splenie leucocythiemin, ju which he also fonnd erystals evidently tho same, and he gives at some length thei: elomical renctions, which are somewhat peculiat, lut from which he draws no very definite conclusion, except that they are not byrosin, 14 had heen supposed. Under the netion of strong hydrochloric and nitric achds, the erystals became flexible ind nisimed the form of an $\mathrm{S}$ or a $\mathrm{C}$. The same neids dilute dissolvorl them.

Another case? Was reported hy Magitot and Charoot (Gaz. Helnlomaduire, 1860, No. 47).

b. Wuguer (Archiv der Ileilkunde, Jil. p. 379) found crystals answering to this description in a soft, greyish-
'TREATMENT' OF IN'TERMITTEN'L FEVER BY CARBBOLIO ACLI).

Trumslated by Dr. 1I. Trek, from Wien. Med. Presse, Mitcli 19, 1871.

Dr. Treutacir reports eight cases of intermittent fever promptly cured by carbolic acid. Itis formula is :-

P. Acidi carbolici, gr. iij. ;

Inf. gent., $\xi \mathrm{v}$.;

Syr. simpl., zi.

M. Dose, 3i. ter die.

IIis article closes thus :

1. Carbolic acid is an admirable remedy for intermittent fever, even for obstinate cases which hive resisted quinine.

2 . Its action is speedy and certain, and it requires such a sinall amount that it cannot possibly have any injurious effect on the system.

3. The average amount required was four and onc-eiglith grains.

4. It costs only one-thirty-fifth of what quinine does, and so is to be preferred for the poor.

5. This successful use of carbolic acid proves that the action of quinine in intermittent fever is antiparasitic.

6. It also favors the opinion that intermittent fever is the result of a blood poison.

\section{Selected oflupers.}

\section{SPON'TANEOUS FRACTURE.}

By David W. Cuenem, M.D., Boston.

Fractures of the shafts of long bones, when occurring in connection with a slight, or almost insensible injury, are usually ascribed, and correctly, to one of four diatheses, or local discases; vi\%.: rachitis, mollities, caries or cancer.

yellow thrombus, consisting almost entirely of white cells, and filling a branch of the portal vein, in a woman who died sndelenly in childhed.

Similar crystals havedescrilsed heen mul figured (Forster's Atlas der Putls. Anat., taf'. xxxiii., firr. 1) as oceurring in sputa in a case of nctute hronchitis, in at myxomm of tho optic nervo, and in the thickened mucus of a dilated billiary pisssige.

The fict of these crystals being found in connection with these well-mnked cases of splenic lencocy themin, the character of the clots in which they ospecially ubounded in the case reported hy me, and most of all their occurrence in a rlot of the same chamacter in the case reported hy Wagner, seems to slow some conmection between their formation and thac presence of an minnstul number of white corpuseles; while on the other hand the comditions moler which they (kupposing them to be the sime chemicinlly as they undoubtedly are in form) were found by Forster are entirely incompatiblo with such an hypothesis. 
When occurring in bones not affected by either of these discases, such lesions are quite rare, and must be classed by themselves. It is to this class we apply the term spontancous fracture.

\section{Casf.}

$\Lambda$ young lady, of rather delicate health; pallid, lymphatic and predisposed to scrofula, fell upon the ice, and struck upon the left shoulder and arm. 'The injury was considered by herself a trivial onc, and but little treatment was arlopted. Dull pains in this arm, however, gradually came on, and recurred fiequently for seven wecks. There was no external sign of local injury during all this period. Gentle fictions and applications were used; the injury was regarded as a contusion, and the patient continued to follow her usual morle of life.

At the end of seven wecks, she was, one morning, walking down a flight of stairs, being about, to go out, when a book she was carrying in her left hand, fell to the floor, and she exclaimed to her companion that she had a violent pain, and could not raise her left arm.

When this occurred her right arm was towards the banisters, and her left entirely away from any object or person. 'The book which she was carrying was of moderate weight.

She now complained of fecling faint, and was taken into a room aljoining the landing of the stairs where the accident happened, and laid upon a bed.

Ilaving been sent for, I saw her soon afterwards, and found a fracture of the sliaft of the left humerus, near the surgical neck. The signs of this fracture were-deformity; bony erepitus when the arm was lengthened and rotated; no rotation of the heal with the slaft ; a positive hinge in the upper third of the shaft; pain and entire helplessness. There was no bruise, no swelling, redlening, fluctuation or sinus. The bone did not appear at all enlarged. The ends of the fracture felt rounded off and pointed.

\section{Trentment.}

$\Lambda$ moderate pad of soft cotton wadding was put in the axilla; a straight splint, padded, was applied to the inside of the arin; a shonlder-cap splint of $A$ hl, padded, compressed the deltoid muscle, and extended down to the external condyle. Extension having been made, the splints werc bandaged on. 'The double triangle of Mayor was now applied, by means of two large handkerchiets, the apices of the triangle meeting at the elbow.
This apparatus was continued for four weeks, with occasional slight re-adjustment. At the end of four weeks, the splints were taken off, and the union was found to be good; the head of the bone rotating with the shaft, and a very considerable, ovoidshaped mass being felt around the scat of fiacture.

The arm was supported in a sling for two weeks more, and then left to itself. It had thus united, firmly and without pain, in about the usual length of time which bones of that size require to repair a break.

\section{RemakKs.}

Neither before, nor since that time, now eighteen months ago, has the patient cxperienced any similar fractures, or a tendency to them. Her health is moderately good; and she is, and has been, of active habits.

The fact of fracture is beyond question; the immediate cxciting canse was absolutely nothing in the way of effort, or injury. 'The book fell because the arm broke; just as old people sink down prostrate because the neck of the femur gives way in advanced age.

Our patient was young, and had none of the symptoms or antecedent causes to which a tendency to fracture is ascribed. She had experienced a fall, followed by continuous local pain. Is it not fair to conclude that the blow had given rise to local inflammation of the bone, followed by absorption, atrophy and fracture?

If this be a correct explanation, the prompt repair of the injury is remarkable. It would seem as if Nature had endured progressive atrophy, and forborne resistance to disintegration, until the bone gave way and the rupture was complete, when immediately lier forces were roused by the shock, and were set at work actively to repair damages.

We have in this, perliaps, an explanation of the large callus which was formed; for, although the misplacement of the bones was remedied by splints, so that the arm came out of the apparatus of good length, even and uniform with the other, yet the provisional callus was as large as we see in very badly misplaced fiactures. It is now well known that in fractures perfectly apposed and retained, union takes place from surface to surface, by the IIaversian canals, without any marked provisional callus; while in finctured bones whose ends have shot by cach other an inormous ball of provisional callus is thrown out.* 'This plastic material is from three sources: the Haver- 
sian canals and periosteum of the medullary cavity (medullary membrane), the periosteum outside the bone, and even from the connective tissues around it.*

Does it not then seem probable that in this fracture from degeneration and atrophy, there was little power of repair in the fiactured ends, and therefore, although the ends were kept well in apposition, the repair took place from the outer periosteum and surrounding tissues, and by a large provisional callus? Just so we see Nature, by a supreme effort, patch up the dangling leg of the lamb, or chicken, which is kept in motion by the animal, and repairs with an cnormous callus.

In a similar way I have seen a fractured clavicle in a child, although never rested and never treated, because not recognized, recover while in motion, with a large provisional callus.

'The singularity of the accident, the absence of exciting cause and the peculiarity in the repair, combine to render this a case of much interest, although, as we shall presently show, it is not a unique one.

I had fresh in mind the case of an old lady who was brought to the hospital, having fractured the shaft of the femur in the middle, by being lifted and turned in bed. In this case the limb was put in an apparatus and kept at perfect rest for six weeks. A projection forming around the fracture was thought to be a callus, and our disap)pointment was great when it was found that no mion had taken place, and to discover, after death, a mass of' osteoid cancer filling and thimning the shaft of the bone, and projecting in every direction around the firacture. It was natural, then, that much solicitude should be felt as to the result in this case of spontancous fracture, lest it should be found that cancer were the cause of the troulile. * * * * * *

In describing the conditions of spontaneous fracture, Malgaignet says :-

"But a caluse, much more fiequent, and one which has been too often overlooked, is a local inflammation of the osscous tissue. I call thus, by conjecture, an affection which exhibits itself externally in dull pains, which the patient refers to a previous contusion, or to an attack of rheumatism; rarely severe enough to excite constitutional disturbance, and hardly arousing the attention, until, finally, on a very slight effort, a fiacture occurs at the seat of the pain.

- Billroth, Surgicnl Pathology. Ollicr, Regencration of Bones.

+ Malgnigne, Fractures and Dislocations.
"I lave secn a young man of twenty years, strong and of good constitution, fracture his femur by falling from the up. right position down mpon level ground; for some weeks previous he hadexperienced, at the seat of fracture, pains which he had referred to rheumatisin."

" $\Lambda$ majority of the firactures of the long bones by muscular action are prepared for, so to speak, in this way. Nicod gives two remarkable cases. $\Lambda$ journeyman carpenter had, for a month, ricumatic pains, quite acutely, in the left arm; a fracture took place, while he was pressing forcibly upon the handle of a bit-stock which he was turning with the right hand. A laborer broke his right arm while throwing a stone; it appeared that he had always cnjoyed good health, until a month previous, when pains in his right arm increased so rapidly as to prevent his working; but there was never fever, nor loss of appetite a single day." "I could cite similar facts as to firacture of the patella.

"I'herefore, whenever we are obliged to subject the bones to a considerable strain, as in the reduction of old dislocations, 1 regard it as a very important precaution to assure ourselves beforehand whether tho patient has experienced fixed pains at any point of the dislocated limb."

It will readily be seen how important a bearing the causation of spontameous fiactures may have in certain medico-legal questions.

Contrasting spontancous with ununited fractures, it might be said that the former began in an atrophy and ended in reparation; while the latter began in a normal state by an accidental break, and ended in an atropliy, without power of repair.

We append the following case, in point, from the report of the Clinical Suciety, taken from the Itondon Isancel of December $3 \mathrm{~d}, 1870:-$

" $\mathrm{Mr}$. 1)urham related a remarkable case of spontancous fiacture of the femur. When lirst seen by lim, the patient, a professional man, was seated, half-dressed, in an casy-chair. Ile thought himself capable of walking about, and was surprised to find this impossible. 'l'he right femur was found broken at the junction of the upper and middle thirds, the limb being shortened by three inches. Three months previously, the patient had fallen down stairs and hurt his thigh; but he soon felt nothing of the injury, which he thought a trifling one. Seven weeks, later, however, he began to have aching pain in the thigh, which was considered 
and treated as neuralgia; and when this had lasted three weeks, he felt, on going to bed one night, a sudden increase in the pain, and fell on to his bed in great agony. Next morning, he could not move the thigh, which was much swollen. IIe was quite unconscious of having subjected the limb to any sudden strain.

"A fter a few days, the swelling and pain diminished, and he got up, but could not walk about; and it was about ten days after, that Mr. Durham, visiting him for the first time, in consultation, found his thigh broken. Under treatment the bone united; in the course of four months the paticnt could move about; two months later, he returned to professional work. IIe remains quite well. Mr. Jurham thought it probable that at the time of the fall some injury of the bone had taken place, which had been followed by gradual interstitial degeneration and absorption of bony tissne, instead of healthy repair, and had led to spontaneous fracture of the bone. 'The patient had, it seemed, been subjected to great worry, and wear and tear of brain, and Mr. Durham suggested the relation which may exist between overwork or excitement of brain and defective nutrition of bonc."

\section{POISONING BY SULPIATE OF A'TROPLA.}

By Cumstopuen Jonsstos, M.D., Frofessor of Surgery in the Unisersity of Maryland. Read betore the Baltimore Medical Association.

Mrs.-R. M., aged 50 years, having a cataractous eye, becume the subject of the modified linear operation for extraction by the hand of I)r. ('eorge Reuling.

T'o secure the happy result which a successful surgical procedure promised, a solution of sulphate of atropia was instilled into the eye at, each inspection of the organ, and a small bit of linen cambric moistened with a few drops of the same. lior convenience, I)r. Rr. left in the room of the patient a half ounce of the solution, which contained two grains of the salt, and with a proper caution. On the 11th of February, at 11.30, P.M., l found a message urging me to repair "in haste to Mrs. M., who had poisoned herself by taking wrong medicine." With a stomach pump under my arm, I liurried to the patient, met the doctor at the door-for he had obeyed a summons like that which I had recoived-and when the door opened, a word from the servant, and the exclamation, "atropia," from I)r. li., cxplained the alarm of the family, and the necessity for prompt measures of relicf. About twenty minutes had elapsed since the poison had been swallowed.

As I ran up stair's, I letermined upon the course to be pursued, and acting upon the assumed antagonism of morphia and atropia, injected hypodermically 15 minims (all we had) of Magendie's solution of morphia, sent out for a further supply of it, and without delay introduced a tube into the stomach.

The patient at this time was profoundly insensible, breathing heavily and slowly, and was cold and damp at the extremities. The mouth and pharynx were exceedingly dry, and the tongue as hard as " the way of the transgressur;" the pulse fecble and rating at about 90 , and the pupil of the uncovered eye largely dilated.

We quickly pumped the stomach full of warm water, and reversing the instrument withdrew with it a quantity of dark matter, including powdered ipecacuanha, which, in the first moment of agitation, a friendly hand had administered. $\Lambda$ gain water was introduced, and then promptly withdrawn discolored, and so on, until the warm water returned without a stain; upon which half a tumbler of rye whiskey, properly diluted, was injected, wherenpon the tube was removed.

In the meantime, at about twenty minutes after our arrival, we were able to enploy hypodermically twenty-five additional minims of Magendic's solution, which made a total of forty minims.

For more than an hour the paticnt secmed to improve slowly ; subsequently the pupil began to diminish, and there were indications of a relapse into her former unconscious state. Fearing the possibility of narcotism by morphia, we provided ourselves with sixty grains of caffein-all that conld be obtained-and, accordingly, at this juncture, readjusted the tube, injected the caflein, made soluble in water by acetic acid, and followed it with some very strong, hot colles. We also refieshed the bowel with the same infusion.

All this took time, and as the case halted we set our battery in operation, to accelerate the languishing respiration, applying one pole to the sides and back of the neck successively, and the other to the epigastrimm and along the margins of the ribs and the lower intereostal spaces. Soon the pulse rose a little, respiration became at first stertorous, and then deep, regular and more frequent, and the patient finally revived from her lethargy with the skin warming by sensiblo degrees. 